\title{
Prevalence and clinical significance of SEN-virus and TT- virus infection in chronic HCV patients
}

\author{
Hend Abdalla El-sayed ${ }^{1}$, Nahla Abd El Hamid ${ }^{1}$, \\ Elsaed M. Galal ElBadrawy²,
} Sameh M. Abdel Monem², Fatma Abdelaziz Amer ${ }^{1}$

\section{Abstract}

Background: SEN virus (SENV) and Torque teno virus (TTV) are blood born viruses. Their effect on the development and progress of liver diseases is still unclear. The aim of this study was to determine the prevalence and effect of SENV and TTV among chronic hepatitis C (CHC) patients.

Patients and Methods: Two hundred patients with $\mathrm{CHC}$ were the subjects of this work. A single blood sample was collected from each patient. Thorough clinical examination and relevant laboratory and radiological investigations were done. SENV and TTV were tested for by Polymerase Chain Reaction (PCR).

Results: SENV was identified in 3 (1.5\%) and TTV was found in 21 $(10.5 \%)$ of investigated patients. No statistically significant difference was detected as regards clinical status, laboratory findings or radiological examination between SENV or TTV positive and negative patients.

Conclusion: SENV and TTV exist among CHC patients. They had insignificant implications on the course or progression of liver diseases.
1 Medical Microbiology and Immunology Department, Faculty of Medicine,

Zagazig University, Egypt.

2 Tropical Medicine Department, Faculty of Medicine, Zagazig University, Egypt.

Contact information:

Prof. Fatma Abdelaziz Amer.

”egyamer@yahoo.com
Keywords
Chronic Hepatitis C, SENV,
TTV, Egypt.

\section{Introduction}

HCV infection is a public health problem in Egypt, the country with the highest prevalence rate worldwide. With the introduction of the direct acting antivirals (DAAs) active against HCV in 2014, the story has seemed to come to the end. In order to achieve the objective 
of eradication of HCV by 2030, many DAAs are available and are easily accessible in Egypt including sofosbuvir, daclatasvir, simeprevir, idvipasivir, ombitasvir, paritaprevir and ritonavir. Guidelines for treatment of various categories of Egyptian HCV patients have been developed by the National Committee for Control of Viral Hepatitis (NCCVH) and are being regularly updated [1]. For better management of $\mathrm{CHC}$ patients it is important to assess the impact of concomitant infections on the clinical course and the progression of the disease.

In the last few years, SENV and TTV have been described as new blood-borne, hepatotropic viral agents with possible hepatic pathogenicity [2].

SEN virus (SENV) is the latest virus proposed as a cause of unknown hepatitis cases. The virus is a circular, single-stranded DNA virus, with around 3800 nucleotides long and nearly $26 \mathrm{~nm}$ size. It is non-enveloped and has a minimum of three ORFs [3]. In the base of investigations on ORF1 sequences, SENV has been classified in the Anellovirusgenus [4]. Nine genotypes (A to I) with about $25 \%$ differences in nucleotide sequence are known [5]. Among the nine genotypes, SENV-D and SENV-H genotypes are the most frequently isolated from cases of (non- A to E) hepatitis. However, they are also frequent in the sera of healthy blood donors [6]. SENV is ubiquitous with distinct geographic variation [7].

TTV has been discovered in 1997 (Japan) in the bloodstream of a patient with post-transfusion hepatitis. It was the first human virus with a singlestranded circular DNA genome to be identified [8]. TTV has recently been classified as the Alphatorque virus genus within the Anelloviridae family by the International Committee on Taxonomy of Viruses (ICTV). Thus far, five main genetic groups (Groups 1-5) involving at least 39 genotypes have been identified based on phylogenetic analysis.

SENV and TTV are identified among wide ranges of populations including intravenous drug users [9], hemophilic and thalassemic patients [10], pa- tients on maintenance hemodialysis [11], HIV positive [12] and patients with hepatic disease [8]. Lin et al. have reported that SEN-V is sensitive to interferon (IFN) therapy [13]. After the stoppage of IFN therapy on HCV patients co-infected with SENV, the later was eradicated in $77 \%$ while the former was eliminated in $38 \%$ of patients. These reflect the higher sensitivity of SENV virus to IFN therapy than that of HCV. Combined treatment with ribavirin (RBV) therapy does not affect SENV response to IFN therapy in contrast to what occurs in HCV infection [14].

The response rate (62-83\%) of treatment with INF of cases of CHC co-infected with TTV is the same whether RBV is added or not [15]. Moreover, the response of HCV to IFN/RBV therapy is not influenced by TTV concurrent infection [16].Additionally, the impact of SENV and TTV on the development of and progression of hepatic diseases is controversial [17].

We carried out this study to determine the prevalence of both SENV and TTV among HCV infected individuals in Egyptian patients and to detect their clinical significance.

\section{Patients and methods}

\section{Study design}

This cross sectional study was done in the Medical Microbiology and Immunology Department, Zagazig, Faculty of Medicine and the University Hospitals. The study protocol was reviewed and approved by the Institutional Review Board (IRB). A written informed consent was obtained from all patients.

\section{Patients and samples}

Two hundred patients with chronic CHC infection (positive quantitative PCR for HCV for more than 6 months) were enrolled in the study. They were HBs-Ag negative and had no history of other viral or autoimmune hepatitis. They were 92 males 
and 108 females with ages ranging from (29-90) years, (M \pm SD: $55.2 \pm 14.5)$. For all patients, complete clinical assessmentand abdominal ultrasonography were done.

Blood samples were collected and serum separated for liver function tests; aspartate aminotransferase (AST), alanine aminotransferase (ALT), albumin andbilirubin. All were measured by using (SAT 450 turbidimetric assay, ELitech, USA). Quantitative PCR for HCV was done by Taq Man Assay Reagents, Applied Biosystems (Thermo Fisher Scientific, USA), using the 7500 fast Real Time PCR system with lower limit of detection $15 \mathrm{IU} / \mathrm{ml}$ (the procedure and primers used according to Abate et al. [18]). The remaining sera were stored at $-80^{\circ} \mathrm{C}$ until used for SENV and TTV detection.

\section{Extraction of DNA from serum}

DNA was extracted from $200 \mu \mathrm{L}$ serum using Thermo Scientific, Gene JET Viral DNA and RNA Purification kit (Thermo Fisher Scientific, USA) according to the manufacturer's instructions.

\section{Amplification and detection}

SENV. The following components was added for each $20 \mu \mathrm{L}$ reaction: $10 \mu \mathrm{L}$ DreamTaq Green PCR Master Mix (2X), 20 pmol of each primer (Thermo Fisher Scientific, USA) (sense primer for SENV-D, "5'-GTAACTTTGCGGTCAACTGCC-3"; ; sense primer for SENV-H, "5'-GGTGCCCCTWGTYAGTTGGCGGTT-3" " [W = A or T]; universal antisense primer, "5'-CCTCGGTTKSAAAKGTYTGATAGT-3" " $[K=G$ or $T, S=C$ or $G$, and $Y=C$ or $T]$ ]) [19] and $5 \mu \mathrm{L}$ DNA template. They were amplified in a thermal cycler (Biometra, Germany) for 40 cycles. Each cycle consisted of denaturation at $95^{\circ} \mathrm{C}$ for 60 seconds, primer annealing at $55^{\circ} \mathrm{C}$ for 30 seconds, and extension at $72^{\circ} \mathrm{C}$ for 60 seconds, with a final extension step at $72^{\circ} \mathrm{C}$ for 10 minutes.

TTV. A $20 \mu \mathrm{l}$ PCR mixture containing 10 $\mu$ LDreamTaq Green PCR Master Mix (2X), 20 pmol of each primer(Thermo Fisher Scientific, USA) (Sense primer; "5'-GCTACGTCACTAACCACGTG-3" \& antisense primer; "5'-CTBCGGTGTGTAAACTCACC-3" [20] and $5 \mu \mathrm{L}$ DNA template. It was amplified using a thermo-cycling program that consisted of an initial denaturation for 9 minutes at $95^{\circ} \mathrm{C}$; and then 55 cycles of 20 seconds at $95^{\circ} \mathrm{C}, 20$ seconds at $55^{\circ} \mathrm{C}$, and 30 seconds at $72^{\circ} \mathrm{C}$. Amplicons were also kept at $72^{\circ} \mathrm{C}$ for 5 minutes for further polymerization.

\section{Statistical data analysis}

The statistical analysis was performed using IBM SPSS Statistics, version 24 (IBM; Armonk, New York, USA). Continuous data were expressed as means \pm standard deviation (SD) and compared using Student's T test. Categorical variables were expressed as percentage and compared using chi-square $\left(\chi^{2}\right)$ test and Fisher's exact probability test. A P value of $\leq 0.05$ was considered significant

\section{Results}

\section{Prevalence of SENV and TTV among chronic HCV patients}

Out of 200 chronic HCV patients, 3 were positive for SENV-H demonstrated by the detection of a band of 230bp on gel electrophoresis. SENV-D was not detected in any case. Listed below are the clinical, physical, radiological and laboratory characteristics of the three cases from which SENV were identified.

\section{Patient 1}

A 60-year old male receiving furosemide, spironolactone, and lactulose. He had moderate ascites. Ultrasonography showed cirrhotic liver. The body mass index was 27. Hemoglobin level was $11.5 \mathrm{~g} /$ $\mathrm{dL}$, platelet count was $65 \times 103 \mathrm{U} / \mathrm{L}$ and total leucocyte count was $2.4 \times 103 \mathrm{U} / \mathrm{L}$. The INR was 1.4. Liver function test results were: serum albumin 2.9 
g/dL, total bilirubin $25.6 \mu \mathrm{mol} / \mathrm{L}, \mathrm{ALT} 48 \mathrm{U} / \mathrm{L}$ and AST $65 \mathrm{U} / \mathrm{L}$, Alpha feto protein $20 \mathrm{ng} / \mathrm{ml}$ (ELISA kit; DiaMetra, Milano, Italy), antinuclear antibodies; negative (ANA ELISA kit, AESKULISA, Germany) and serum creatinine $0.9 \mu \mathrm{mol} / \mathrm{L}$ (SAT 450 turbidimetric assay, ELitech,USA). The patient was diagnosed to have ascites and was classified as Child Class B with Child Pugh Score 8 and MELD Score 12. He had no history of hemodialysis, positive history of blood transfusion (9 unit of blood), and positive history of previous surgery.

Virology testing revealed negative HBsAg and positive HCV G4a with a viral load of $5.3 \log 10$ (copies $/ \mathrm{mL}$ ) TaqMan Real Time PCR with lower limit of detection $15 \mathrm{IU} / \mathrm{ml}$.

\section{Patient 2}

A 72 year-old female receiving furosemide, spironolactone, lactulose, liver support, vitamine $\mathrm{K}$ and rantidine. She had mild ascites. Ultrasonography showed cirrhosis and focal mass. The body mass index was 18. Hemoglobin level was $10.5 \mathrm{~g} / \mathrm{dL}$, platelet count was $92 \times 103 \mathrm{U} / \mathrm{L}$ and total leucocyte count was $9 \times 103 \mathrm{U} / \mathrm{L}$. The INR was 1.7. Liver function test results were: serum albumin 2.4 $\mathrm{g} / \mathrm{dL}$, total bilirubin 29.07 $\mathrm{mol} / \mathrm{L}$, ALT 52U/L and AST 63U/L. Alpha feto protein 500 ng/ml (ELISA kit ;DiaMetra, Milano, Italy), antinuclear antibodies; negative (ANA ELISA kit, AESKULISA, Germany) and serum creatinine $0.9 \mu \mathrm{mol} / \mathrm{L}$ (by SAT 450 turbidimetric assay, ELitech, USA). The patient was diagnosed to have hepatocellular carcinoma and was classified as Child Class B with Child Pugh Score 9 and MELD Score 14.

She had no history of hemodialysis or surgery and positive history of blood transfusion (6 units). Virologic testing revealed negative $\mathrm{HBsAg}$ and positive HCV G4a with a viral load of $6.3 \log _{10}$ (copies/mL) TaqMan Real Time PCR with lower limit of detection $15 \mathrm{IU} / \mathrm{ml}$.

\section{Patient 3}

A 53 year-old female receiving spironolactone, lactulose, liver support, vitamin K, rantidine and calcium supplement. Ultrasonography showed cirrhotic liver. The body mass index was 23 . On examination she had hemoglobin level of $9 \mathrm{~g} / \mathrm{dL}$, platelet count of $110 \times 103 \mathrm{U} / \mathrm{L}$ and total leucocyte count of $9 \times 103 \mathrm{U} / \mathrm{L}$. The INR was 1.2. Liver function test results were: serum albumin $3.3 \mathrm{~g} / \mathrm{dL}$, total bilirubin $22.2 \mu \mathrm{mol} / \mathrm{l}$, ALT 47U/L and AST 54U/L. Alpha feto protein was 30ng /ml (ELISA kit;DiaMetra, Milano, Italy), antinuclear antibodies; negative(ANA ELISA kit, AESKULISA,Germany) and serum creatinine was $79.5 \mu \mathrm{mol} / \mathrm{l}$ (SAT 450 turbidimetric assay, ELitech,USA) The patient was diagnosed to have microcytic hypochromic anemia and was classified as Child Class B with Child Pugh Score 9 and MELD Score 14.

She had no history of hemodialysis or surgery, positive history of blood transfusion (4 units). Virologic testing revealed negative $\mathrm{HBsAg}$ and positive HCV G4a with a viral load of $6.14 \log _{10}$ (copies/ $\mathrm{mL}$ ) TaqMan Real Time PCR with lower limit of detection $15 \mathrm{IU} / \mathrm{ml}$.

Out of 200 chronic HCV patients, 21 (10.5\%) were positive for TTV as demonstrated by visualization of a band of $199 \mathrm{bp}$ on gel. A. Among the studied CHC patients; there were 92 male and 108 female with mean age of 55.2. The level of HCV RNA log 10 by real time PCR ranged from (4.307.59) copies/mL. On ultrasonographic examination; cirrhosis and focal mass were found in $27.5 \%$ of patients and cirrhosis only was detected in 53.5\% of them. while $14 \%$ of patients had periportal fibrosis. Regarding laboratory investigations; total bilirubin, direct bilirubin, ALT and AST levels were elevated in $32 \%, 29.5 \%, 64 \%$ and $61 \%$ of patients respectively. Regarding risk factors; positive history of blood transfusion, positive history of previous surgery, positive history of Tattooing were reported in $61 \%, 74.5 \%$ and $27 \%$ of patients respectively, as shown in Table 1. 
Table 1. Demography and characteristics of 200 investigated patients .

\begin{tabular}{|c|c|c|}
\hline \multirow{2}{*}{ Characteristic } & \multicolumn{2}{|c|}{ Patients } \\
\hline & no. & $\%$ \\
\hline \multicolumn{3}{|l|}{ Age (years) } \\
\hline mean $\pm S D$ & \multicolumn{2}{|c|}{$55.2 \pm 14.5$} \\
\hline \multicolumn{3}{|l|}{ Sex } \\
\hline Male & 92 & 46 \\
\hline Female & 108 & 54 \\
\hline \multicolumn{3}{|l|}{ HCV RNA, $\log _{10}$ (copies/mL) } \\
\hline median (range) & 6.2 & $4.30-7.59$ \\
\hline Cirrhosis & 107 & 53.5 \\
\hline Cirrhosis and focal mass & 55 & 27.5 \\
\hline Periportal fibrosis & 28 & 14 \\
\hline \multicolumn{3}{|l|}{ Total bilirubin ${ }^{1}$ (mg/dL) } \\
\hline median (range) & 0.70 & $0.4-3.5$ \\
\hline Elevated & 64 & 32 \\
\hline \multicolumn{3}{|l|}{ Direct bilirubin² (mg/dL) } \\
\hline median (range) & 0.2 & $0.1-1.6$ \\
\hline Elevated & 59 & 29.5 \\
\hline \multicolumn{3}{|l|}{$\mathrm{ALT}^{3}(\mathrm{U} / \mathrm{L})$} \\
\hline median (range) & 54 & $10-177$ \\
\hline Elevated & 128 & 64 \\
\hline \multicolumn{3}{|l|}{$\mathrm{AST}^{4}(\mathrm{U} / \mathrm{L})$} \\
\hline median( range) & 44 & $17-276$ \\
\hline Elevated & 122 & 61 \\
\hline \multicolumn{3}{|l|}{ Albumin 5 (g/dL) } \\
\hline mean $\pm S D$ & \multicolumn{2}{|c|}{$3.8 \pm 0.74$} \\
\hline History of blood transfusion & 122 & 61 \\
\hline History of previous surgery & 149 & 74.5 \\
\hline Tattooing & 54 & 27 \\
\hline
\end{tabular}

HCV: hepatitis C virus, ALT: alanine aminotransferase, AST: aspartate-aminotransferase.

1: Normal level i(0-1mg/dl), ${ }^{2}$ : normal level (0-0.3 mg/dl), 3: normal level (0-40U/L), 4: normal level (0-37U/L), 5: normal level (3.5-5g/dL).

\section{Comparing laboratory and ultrasonography findings}

In 21 cases co-infected with (TTV\&HCV) and 179 cases (HCV positive\& TTV negative), there were no statistically significance difference between both groups ( $\mathrm{P}>$.05), as shown in Table 2.

Table 2. Biochemical and clinical characteristics of 21 positive (TTV plus HCV) and 179 (only positive $\mathrm{HCV}$ ) infected patients

\begin{tabular}{|c|c|c|c|c|c|}
\hline \multirow{3}{*}{ Characteristic } & \multirow{2}{*}{\multicolumn{2}{|c|}{$\begin{array}{l}\text { TTV positive } \\
\text { HCV positive }\end{array}$}} & \multirow{2}{*}{\multicolumn{2}{|c|}{$\begin{array}{l}\text { TTV negative } \\
\text { HCV positive }\end{array}$}} & \multirow{3}{*}{ P-value } \\
\hline & & & & & \\
\hline & No. & $\%$ & No. & $\%$ & \\
\hline \multicolumn{6}{|l|}{ Total bilirubin ${ }^{1}$} \\
\hline Elevated & 6 & 28.6 & 58 & 32.4 & 0.81 \\
\hline \multicolumn{6}{|l|}{ Direct bilirubin ${ }^{2}$} \\
\hline Elevated & 6 & 28.6 & 53 & 29.6 & $>0.99$ \\
\hline \multicolumn{6}{|l|}{$\mathrm{ALT}^{3}$} \\
\hline Elevated & 13 & 61.9 & 115 & 64.3 & 0.81 \\
\hline \multicolumn{6}{|l|}{$\mathrm{AST}^{4}$} \\
\hline Elevated & 10 & 47.6 & 112 & 62.6 & 0.24 \\
\hline \multicolumn{6}{|l|}{ Albumin (g/dL) } \\
\hline mean $\pm S D$ & \multicolumn{2}{|c|}{$4 \pm 0.4$} & \multicolumn{2}{|c|}{$3.8 \pm 0.7$} & 0.1 \\
\hline $\begin{array}{l}\text { HCVRNA, } \log _{10} \\
\text { (copies } / \mathrm{mL} \text { ) }\end{array}$ & \multicolumn{2}{|c|}{$6.14 \pm 0.3$} & \multicolumn{2}{|c|}{$6.08 \pm 0.6$} & .45 \\
\hline Cirrhosis & 9 & 42.9 & 98 & 54,7 & \multirow{3}{*}{.081} \\
\hline $\begin{array}{l}\text { cirrhosis } \\
\text { +focalmass }\end{array}$ & 5 & 23.8 & 50 & 27.9 & \\
\hline $\begin{array}{l}\text { Periportal } \\
\text { fibrosis }\end{array}$ & 7 & 33.3 & 21 & 11.7 & \\
\hline
\end{tabular}

TTV: transfusion-transmitted virus, HCV: hepatitis C virus, ALT: alanine aminotransferase, AST: aspartate-aminotransferase.

1: Normal level (0-1mg/dl), 2: normal level (0-0.3 mg/dl), 3: normal level (0-40U/L), 4: normal level (0-37U/L).

\section{Comparing parental risk factors for TTV}

Between 21 cases co-infected with (TTV\&HCV) and 179 cases (HCV positive\& TTV negative). The history of blood transfusion and history of surgery were significantly higher in patients co-infected with (TTV\& $\mathrm{HCV}$ ) than the second group, as shown in Table 3. 
Table 3. Comparison parental risk factors between 21 positive patients (HCV + TTV) and those 179 negative for co-infection with TTV.

\begin{tabular}{|c|c|c|c|c|c|}
\hline \multirow{3}{*}{ Characteristic } & \multirow{2}{*}{\multicolumn{2}{|c|}{$\begin{array}{l}\text { TTV positive } \\
\text { HCV positive }\end{array}$}} & \multirow{2}{*}{\multicolumn{2}{|c|}{$\begin{array}{l}\text { TTV negative } \\
\text { HCV positive }\end{array}$}} & \multirow{3}{*}{ P-value } \\
\hline & & & & & \\
\hline & No. & $\%$ & No. & $\%$ & \\
\hline $\begin{array}{l}\text { History of blood } \\
\text { transfusion }\end{array}$ & 17 & 81 & 105 & 58.7 & $.048^{a}$ \\
\hline $\begin{array}{l}\text { History of } \\
\text { previous surgery }\end{array}$ & 20 & 95.2 & 129 & 72.1 & $.018^{a}$ \\
\hline \multirow[t]{2}{*}{ Tattooing } & 3 & 14.3 & 5 & 28.5 & .17 \\
\hline & & \multicolumn{4}{|c|}{ a: $P<.05$ : statistically significance. } \\
\hline
\end{tabular}

\section{Discussion}

Further achievements have been made to bring $\mathrm{HCV}$ to the era of eradication. After the approval of DAAs in 2011, the therapeutic revolution against $\mathrm{HCV}$ involves pangenotypic HCV therapy which is a regimen combining two or three, $2^{\text {nd }}$ generation DAAs. Duration of therapy is 8-16 weeks depending on the stage of fibrosis, genotype, baseline viral load, prior treatment history and pre-existing resistance-associated variants. Most of these combinations have a high antiviral potency, fair tolerance and a reduced pill burden [21].

Contrary to studies carried out in Egypt or elsewhere, [11, 22-24] very low level of prevalence of SENV was identified in the current work. This can beattributed to technical or host factors. Technical factors include differences in the sensitivities of the assay systems [23], or primers used. In 2015, Abuodeh et al., concluded that the extensive variation in sequence of SENV made it difficult to select a primer set that can detect all virus genotypes [25]. Human factors are based on the possibility of the ubiquitous distribution of SENV that could be affected by collaborations among behavioral, social, biological and climate factors [10]. Furthermore, the rate of clearance of SENV can contribute to variable rate of SENV among different populations. Umemura and colleagues in 2001, reported that about $77 \%$ of post transfusion infected patients have cleared the virus within 6 months after being infected and that $13 \%$ appeared to have chronic SEN virus infection [26].

The three cases positive for SEN-V in the current work showed history of parenteral exposure through blood transfusion, tattoing and surgical procedures. These support the idea that SENV is transmitted via parental route.

The prevalence of TTV was $10.5 \%$ among $\mathrm{CHC}$ patients. Great variations in the prevalence of TTV have been reported in various studies. The prevalence of TTV infection in the current work falls within range reported before $[27,28]$. However, it is lower than those identified in several other studies; $84.9 \%$ in Qatar, 90\% in Pakistan and 47\% in Taiwan [24$25,29]$ respectively. These variations can beattributed to differences in the quantity of viral DNA in the sera, different primers used, differences in the sensitivities of methods of detection, different study populations and different risk factors.

The prevalence of TTV was more in patients aged (50-70) years. This may be due to presence of large number of the patients in this study in this age group.

The statistically- significant differences as regards history of blood transfusion and history of previous operations in patients positive for TTV versus TTV negative patients ( $p$ - value <.05) support the idea that TTV is transmitted parentally. This was in agreement with other studies [7, 10-11] which reported wide ranges of infection in intravenous drug users, hemophilic and thalassemic patients, patients on maintenance hemodialysis, HIV positive and patients with hepatic disease. The insignificant difference regarding age, gender can be attributed to characters of the study population. On the other hand, the insignificant difference as regards tattooing is due to small number of cases practicing this procedure.

This study found no statistically significant difference between TTV positive and TTV negative 
individuals regarding the level of AST, ALT, other laboratory and ultrasonography finding which agree with study of Bostan et al. [30], but contrary to other studies [8, 31]. Rocchi et al. [32] attributed the pathologic role of TTV to the capability of some isolates to activate production of pro-inflammatory cytokines, thus accelerate the severity of inflammatory disorders.

\section{Conclusion}

The present study includes a small number of cases positive for SENV which does permit a definite conclusion. However, there was no significant correlation as regards the mean age or sex between TTV positive and TTV negative patients. TTV does not appear to have an impact on progression of hepatic diseases. The parenteral route seems to be critical in the transmission of TTV.

\section{References}

1. Amer FA. Large-scale hepatitis C combating campaigns in Egypt and Georgia; past, current and future challenges. J Infect DevCtries 2018; 12(6):404-414.

2. MoghaddamS,Mousavi S, Alavian S. Is SEN Virus a Major Concern in Hemodialysis and Liver Transplantation?, Hepatitis Monthly 2009; 9: 50-59.

3. Tanaka Y, Pfeiffer R, Yeo AE. PCR-probe capture hybridization assay and statistical model for SEN virus prevalence estimation. J Med Virol 2004; 73(1):123-30.

4. Rizvi M, Jahan S, Azam M, Ajmal MR, Shukla I, Malik A, et al. Prevalence and assessment of role of SEN virus in acute and chronic hepatitis in India. Tropic Gastroenterl 2013; 34(4): $227-$ 234.

5. Azimeh SH and Bouzari M. Detection of SENV Virus in Healthy, Hepatitis B- and Hepatitis C-Infected Individuals in Yazd Province, Iran. Iran Biomed J 2016; 20(3):168-174

6. Sharifi Z, Mahmoodian-Shooshtari M, Talebian A. The Prevalence of SEN Virus Infection in Blood Donors in Iran. Arch Iranian Med 2008; 11(4):423- 426.

7. Akiba J, Umemura T, Alter HJ, Kojiro M, Tabor E. SEN virus: epidemiology and characteristics of a transfusion-transmitted virus. Trandusion 2005; 45:1084-1088.
8. Spandole S, Cimponeriu D, Mariana LB, Mihaescu G. Human anelloviruses: an update of molecular, epidemiological and clinical aspects. Arch Virol2015; 160:893-908.

9. Pirovano S, Bellinzoni M, Matteelli A, Ballerini C, Albertini A, Imberti L. High prevalence of a variant of SENV in intravenous drug user HIV-infected patients 2002; 68(1):18-23.

10. Karimi-Rastehkenari A and Bouzari M. High frequency of SEN virus infection in thalassemic patients and healthy blood donors in Iran. Virology Journal 2010; 7:1.

11. Amer FA. Surveillance and impact of occult hepatitis B virus, SEN virus and TT virus among hemodialysis patients with chronic hepatitis C virus infection in the Eastern Province of Egypt. Joint Event on GLOBAL PHARMA SUMMIT \& 2nd International Conference on GASTROENTEROLOGY AND HEPATOLOGY, Bangkok, Thailand. Asian J Biomed Pharmaceut 2018; DOI: 10.4066/2249-622X-C5-013.

12. Najafimemar Z, Tabarraei A, Talei G, Moradi A. Prevalence and Genotyping of Torque Teno Virus in HBV/HIV and Chronic HBV Patients in Iran. Iran Biomed J 2018; 22(5):338-344.

13. Lin JG, Goto T, Nakane K. Clinical significance of SEN-virus on interferon response in chronic hepatitis C patients. J Gastroenterol Hepatol 2003; 18(10):1144-1149.

14. Mohammad SM, Hamideh SM, Moayed SA. Is SEN Virus a Major Concern in Hemodialysis and Liver Transplantation? Hepatitis Monthly 2009; (9):50-59.

15. Dai CY, Yu ML, Chuang WL, Hou NJ, Hou C, Chen SC, et al. The response of hepatitis $C$ virus and TT virus to high dose and long duration interferon-alpha therapy in naïve chronic hepatitis $C$ patients. Antiviral Res 2002; 53:9-18.

16. Moreno J, Moraleda G, Barcena R, Mateos M, Campo S. Response of TT virus to IFN plus ribavirin treatment in patients with chronic hepatitis C, World J Gastroenterol.2004; 10(1): 143-146.

17. Javad MK, Yaghobi R, Iravani MS, Geramizadeh B, Moayedi J. Association between TT Virus Infection and Cirrhosis in Liver Transplant Patients. Hepat Mon 2015; 15 (9).

18. Abate ML, Manzini P, Negro F, Baldi M, Saracco G, Piantino P, et al. Detection of hepatitis $C$ virus RNA by reverse-transcriptase and polymerase chain reaction: clinical applications of quantitative analysis. ClinDiagnVirol 1994; 1(5-6):289-97.

19. Tanaka Y, Primi D, Wang RY. Genomic and molecular evolutionary analysis of a newly identified infectious agent (SEN virus) and its relationship to the TT virus family. J Infect Dis 2001; 138:359367.

20. Ergünay $K$, Gürakan $F$, Usta $Y$, Yüce $A$, Özen $H$, Karabulut $E$, et al. Detection of TT virus (TTV) by three frequently-used PCR methods targeting different regions of viral genome in children with cryptogenic hepatitis, chronic B hepatitis and Hbs carriers. Turk J Pediatr 2008; 50:432-437. 
21. Scotto R, Buonomo AR, Moriello NS, Maraolo AE, Zappulo E, Pinchera B, Gentile I, et al. Real-World Efficacy and Safety of Pangenotypic Direct Acting Antivirals Against Hepatitis C Virus Infection. Reviews on Recent Clinical Trials 2019; DOI:19030615465010. 2174/1574887114666

22. Omar M, Saad El-Din S,, Fam N, Diab M, Shemis M, Raafat $M$, et al. SEN Virus Infection in Egyptian Patients With Chronic Hepatitis C and Patients Undergoing Hemodialysis. Medscape J Med 2008; 10(12): 290.

23. Elsherbiny N, Hassan E, Ahmed A, Abd El-RehimA, Abd El Rehim N, Hassany S. Does SEN virus (SENV) infection affect the progression of chronic hepatitis $\mathrm{C}$ or $\mathrm{B}$ among Egyptian patients?African J Microbial Res 2015; 9(23):1504-1512.

24. Kao JH, Chen W, Chen PJ, Lai MY, Chen DS. SEN virus infection in patients with chronic hepatitis C: preferential coinfection with hepatitis $C$ genotype $2 \mathrm{a}$ and no effect on response to therapy with interferon plus ribavirin. J Infect Dis 2003; 187:307-10.

25. AbuOdeh R, Al-Mawlawi N, Al-Qahtani A, Bohol M, Al-Ahdal MN, Hasan HA, et al. Detection and Genotyping of Torque Teno Virus(TTV) in Healthy Blood Donors and Patients Infected With HBV or HCV in Qatar. J Med I Virol 2015; 87:1184-1191.

26. Umemura $T$, Yeo AE, Sottini A, Moratto D, Tanaka $Y$, Wang $R Y$, et al. SEN virus infection and its relation to transfusionassociated hepatitis. Hepatology 2001; 33:1303-1311.

27. Brandhagen DJ, Charlton MR, Gross JB. Prevalence and clinical significance of TT-virus co-infection in patients with chronic hepatitis $C$ treated with interferon. Hepatology 1998; 28:367A.

28. Trimoulet $P$, Le'dinghen $V$, Ekouevi $D$, Bernard $P$, Merel $P$, Che^ne G, et al. TT Virus Infection During Chronic Hepatitis C. Am J Gastroenterol 2000; 95 (7):1766-1769.
29. Hussain $T$, Manzoor S, Waheed $Y$, Tariq $H$, Hanif $K$. Phylogenetic analysis of torque teno virus genome from Pakistani isolate and incidence of co-infection among $\mathrm{HBV} / \mathrm{HCV}$ infected patients. Virol J 2012; 9:320-329.

30. Bostan N, Amen NE, Bokhari H. Current and Future Prospects of Torque Teno Virus. J Vaccines Vaccin 2013, S:1. DOI: 10.4172/2157-7560.S1-00431.

31. García-Álvarez M, Berenguer J,Álvarez E, Guzmán-Fulgencio M, Cosín J,Miralles $\mathrm{P}$ et al. Association of torque teno virus (TTV) and torque teno mini virus (TTMV) with liver disease among patients coinfected with human immunodeficiency virus and hepatitis C virus. Eur J Clin Microbiol Infect Dis 2013; 32:289297.

32. Rocchi J, Ricci V, Albani M, Lanini L, Andreoli E, Macera L, et al. Torquetenovirus DNA drives proinflammatory cytokines production and secretion by immune cells via toll-like receptor 9. Virology 2009; 394:235-242.
Publish in The International

Arabic Journal of Antimicrobial Agents

The Journal is an open access peer-reviewed journal that publishes scientific papers about all aspects of antimicrobials. The journal will publish original research articles, reviews, brief reports and case reports dealing with basic and clinical antibacterial agents, antiviral, antiprotozoals, antituberculuous, antifungal and antihelminthes agents. All manuscripts must be prepared in English, and are subject to a rigorous and fair peer-review process. Accepted papers will immediately appear online. The journal aims to advance the knowledge, attitude and the research of chemotherapy in the Arabic world in cooperation with international, national scientific and public societies as well as research centers with similar aims and objectives. 